\title{
Phytoremediation of Cadmium-, Copper-, and Lead-contaminated Soil by Salix mucronata (Synonym Salix safsaf)
}

\author{
El-Sayed Mohamed El-Mahrouk \\ Department of Horticulture, Faculty of Agriculture, Kafrelsheikh University, \\ Kafr El-Sheikh 33516, Egypt
}

Eman Abdel-Hakim Eisa

Sakha Horticulture Research Station, Horticulture Research Institute, Agricultural Research Center, Giza, Egypt

\author{
Mahmoud Abdelnaby Hegazi \\ Department of Horticulture, Faculty of Agriculture, Kafrelsheikh University, \\ Kafr El-Sheikh 33516, Egypt
}

Mohamed El-Sayed Abdel-Gayed

Sakha Horticulture Research Station, Horticulture Research Institute, Agricultural Research Center, Giza, Egypt

Yaser Hassan Dewir

Department of Horticulture, Faculty of Agriculture, Kafrelsheikh University, Kafr El-Sheikh 33516, Egypt; and Plant Production Department, College of Food and Agriculture Sciences, King Saud University, Riyadh 11451, Saudi Arabia

\author{
Mohammed Elsayed El-Mahrouk ${ }^{1}$ \\ Department of Horticulture, Faculty of Agriculture, Kafrelsheikh University, \\ Kafr El-Sheikh 33516, Egypt
}

\section{Yougasphree Naidoo}

School of Life Sciences, University of KwaZulu-Natal, Westville Campus, Private Bag X54001, Durban 4000, South Africa

Additional index words. accumulation, antioxidant, contaminating ions, reclamation, Safsaf willow

\begin{abstract}
Phytoremediation is an environmentally friendly and effective method of reducing contaminating ions to very low levels. In this study, the effects of different concentrations of cadmium $(\mathrm{Cd})$, copper $(\mathrm{Cu})$, and lead $(\mathrm{Pb})$ on vegetative growth and the chemical and biochemical compositions of Salix mucronata as well as the potential for phytoextraction of these metals by plant organs were investigated. $S$. mucronata had the highest survival percentage $(100 \%)$ in the presence of $\mathrm{CdCl}_{2}, \mathrm{CuCl}_{2}$, and $\mathrm{Pb}$ acetate up to 80,200 , and $850 \mathrm{mg} \cdot \mathrm{kg}^{-1}$ in soil, respectively. A negative influence of these metals on vegetative and chemical parameters was observed relative to the control plants. The potential role of antioxidant enzymes in protecting plants from oxidative injury was examined by analyzing the antioxidant enzyme activities of plants grown in contaminated and control soils. Enzymatic activities and electrolyte leakage were higher in the plants grown in soil with increasing heavy metals than in the control plants. The bioconcentrating efficiency of $\mathrm{Cd}, \mathrm{Cu}$, and $\mathrm{Pb}$ in plant organs was estimated to be medium [bioconcentration factor (BCF) of 1-0.1]; an exception was the $\mathrm{BCF}$ of $\mathrm{Cu}$ in the roots, which was estimated to be intensive $(\mathrm{BCF}<1)$. Concentrations of $60 \mathrm{mg} \cdot \mathrm{kg}^{-1} \mathrm{CdCl}_{2}, 50$ $\mathrm{mg} \cdot \mathrm{kg}^{-1} \mathrm{CuCl}_{2}$, and $650 \mathrm{mg} \cdot \mathrm{kg}^{-1} \mathrm{~Pb}$ acetate caused significantly higher translocation compared with other levels of each pollutant. The biomass tolerance index was less than 1. Additionally, $S$. mucronata accumulated $\mathrm{Cd}, \mathrm{Cu}$, and $\mathrm{Pb}$ in the following order: roots > stems $>$ leaves. Therefore, the risk of contamination through leaf fall can be minimized. Therefore, $S$. mucronata could be a good candidate for phytoremediation of $\mathrm{Cd}-, \mathrm{Cu}-$, and Pb-contaminated soil.
\end{abstract}

Heavy metal-contaminated agricultural soil is a complex and serious phenomenon that has hazardous effects on the environment and, consequently, on humans, animals, plants, and beneficial microorganisms by influencing and tainting food chains, soil, irrigation or potable water, aquifers, and the surrounding atmosphere (Wuana and Okieimen, 2011). Cadmium (Cd) is an important poisonous element that is not known for any essential biological function. Furthermore, $\mathrm{Cd}$ may cause malfunctioning of metabolic processes (Campbell, 2007). In plants, $\mathrm{Cd}$ causes various types of damage, such as the disturbance of metal homeostasis resulting in iron deficiency in the shoot (Fodor et al., 2005). As a result, the biosynthesis of chlorophylls, the formation of Chl-protein complexes, and the development of thylakoid membranes are highly disturbed (Basa et al., 2014). Copper $(\mathrm{Cu})$ is an important essential micronutrient that participates in many vital physiological functions of plants, including acting as a catalyzer of redox reactions in mitochondria, chloroplasts, and the cytoplasm of cells (Fargasova, 2004) or as an electron carrier during plant respiration (Yruela, 2009). Uptake of $\mathrm{Cu}$ by plants and its toxicity are contingent on the nutritional condition of the plant, $\mathrm{Cu}^{2+}$ concentration in the soil, exposure time, and plant species (Nicholls and Mal, 2003). Increased Cu can damage membranes and produce free radicals in different plant parts (Chen et al., 2000). Lead $(\mathrm{Pb})$ accumulation in plant tissue impairs different morphological, physiological, and biochemical functions in plants, either directly or indirectly, and induces a range of deleterious effects. $\mathrm{Pb}$ causes phytotoxicity by changing cell membrane permeability and reacting with active groups of various enzymes involved in plant metabolism (Pourrut et al., 2011).

Phytoremediation has become an effective and affordable technological solution used to extract or remove metal pollutants from contaminated soil using plants. Plants possess a sophisticated and interrelated network of defense strategies to avoid or tolerate heavy metals or facilitate their de-toxification (Harada et al., 2010). To reduce the harmful impact of free radicals resulting from heavy metal stress, plant cells have developed an antioxidant defense mechanism (Sharma et al., 2012). Tree species have been suggested as appropriate plants for phytoremediation of heavy metal-contaminated soil because they provide several beneficial attributes such as large biomass, genetic variability, established management practices, economic value, public acceptability, and site stability (Pulford and Waston, 2003). To achieve good phytoremediation efficiency, plants should accumulate a significant amount of heavy metals, tolerate soil pollution, and produce a great quantity of biomass under contaminating conditions (McGrath et al., 2002). The advantages of phytoremediation are mainly due to its effectiveness in reducing contaminant ions to very low levels. Moreover, it involves the use of an inexpensive bio-sorbent material (Rakhshaee et al., 2009) applicable to a wide range of toxic metals and radionuclides (Liu et al., 2000) and is a low-cost and environmentally friendly method.

Salix spp. trees are important as a source of biomass for energy purposes (Zalesny 
et al., 2016). Additionally, there has been a growing interest in their use for different environmental purposes and land reclamation, including phytoremediation and phytoextraction of contaminated soils (Dimitriou et al., 2012). Willows are recognized for their phytoremediation potential and phytoextraction of soils contaminated by heavy metals (Vervaeke et al., 2003). Safsaf willow (Salix mucronata), a member of the Salicaceae family, is a popular commercial tree in Egypt that is used for many industrial purposes (Fahmy, 1948). It is indigenous to northern and tropical Africa and widely distributed throughout Egypt and Sudan. It is used for wind screening, planting in damp woodlands, waterside planting, coppicing, and remediation of contaminated sites. $S$. mucronata can absorb some heavy metals; therefore, it has been planted in reclaimed industrial sites and used for small-scale water treatment systems in which wastewater is passed through willow beds, which cleans the water for re-use (Schmidt, 2003). However, there are 552 accepted species names under the Salix genus, with 963 intraspecific ranks for the genus worldwide, including 3 species in Egypt (Fahmy, 1948). A previous study indicated that 34 species of Salix were used for phytoremediation (Kersten, 2015). Of these, phytoremediation of heavy metal-contaminated soil involves S. eriocephala and $S$. discolor for manganese $\left(\mathrm{Mn}^{++}\right)$, iron $\left(\mathrm{Fe}^{++}\right)$, aluminum $\left(\mathrm{Al}^{+++}\right)$, sulfur $\left(\mathrm{S}^{++}\right)$, and magnesium $\left(\mathrm{Mg}^{++}\right)$(Mosseler and Major, 2017), Salix viminalis for sodium $\left(\mathrm{Na}^{+}\right), \mathrm{Mg}^{++}$(Hegedus et al., 2009), and $\mathrm{Cu}^{++}$ (Gsecka et al., 2012), Salix polaris for $\mathrm{Cd}^{++}$, chromium $\left(\mathrm{Cr}^{+++}\right), \mathrm{Fe}++$, zinc $\left(\mathrm{Zn}^{++}\right)$, and molybdenum $\left(\mathrm{Mo}^{++}\right)$(Krajcarova et al., 2016), Salix purpura $\times$ viminalis for $\mathrm{Cu}^{++}$ and nickel $\left(\mathrm{Ni}^{++}\right)$(Drzewiecka et al., 2017), and $S$. matsudana for $\mathrm{Pb}$ (Tang et al., 2017). In general, these studies concluded that although growth and chemical parameters were negatively affected in the presence of heavy metals, these species could be used as phytoremediators to clean contaminated soil. However, there is no report of using $S$. mucronata as a phytoremediator of heavy metal-contaminated soil. Additionally, most previous studies involved acidic soil. Therefore, this study used alkaline soil to study the effects of $\mathrm{Cd}, \mathrm{Cu}$, and $\mathrm{Pb}$ on the growth and chemical and biochemical compositions of $S$. mucronata. The relationships between the concentrations of these metals in plant organs and their concentrations in the soil were determined to facilitate the use of $S$. mucronata to remove these metals from soil.

\footnotetext{
Received for publication 6 Mar. 2019. Accepted for publication 23 Apr. 2019.

We thank the International Scientific Partnership Program (ISPP) of King Saud University for funding this research (ISPP\# 0064) and the Research Support \& Services Unit (RSSU) for their technical support.

${ }^{1}$ Corresponding author. E-mail: threemelmahrouk@ yahoo.com.
}

\section{Materials and Methods}

Plant material. Mature shoot cuttings (1year-old wood) $15 \mathrm{~cm}$ in length and $0.5 \mathrm{~cm}$ in diameter were procured from a 10-year-old mother tree of $S$. mucronata that was grown in the nursery of the Faculty of Agriculture at Kafrelshikh University. The cuttings were cultured in plastic bags $10 \mathrm{~cm}$ in diameter (one cutting per bag) filled with clay soil (Table 1). The cultured bags with cuttings were kept in an air-conditioned plastic greenhouse adjusted to $25 \pm 2{ }^{\circ} \mathrm{C}$, with $40 \%$ to $50 \%$ relative humidity, a photoperiod of $16 \mathrm{~h}$ of light and $8 \mathrm{~h}$ of dark, and light intensity of $300 \mu \mathrm{mol} \cdot \mathrm{m}^{-2} \cdot \mathrm{s}^{-1}$. The cuttings were watered manually every $10 \mathrm{~d}$ using 10 -L watering cans; the same water volume was applied to each bag. After 3 months, homogeneous transplants with an average height of $35 \mathrm{~cm}$ and stem diameter of $0.9 \mathrm{~cm}$ (at the soil surface) were used in this study.

Pollutant treatments and media preparation. Different concentrations of cadmium chloride $\left[\mathrm{CdCl}_{2} * \mathrm{H}_{2} \mathrm{O}\right](20,40,60$, and 80 $\mathrm{mg} \cdot \mathrm{kg}^{-1}$ soil), copper chloride $\left[\mathrm{CuCl}_{2} 2 \mathrm{H}_{2} \mathrm{O}\right]$ $\left(50,100,150\right.$, and $200 \mathrm{mg} \cdot \mathrm{kg}^{-1}$ soil), and lead acetate trihydrate $\left[\left(\mathrm{CH}_{3} \mathrm{COO}\right)_{2} \mathrm{~Pb}_{3} \mathrm{H}_{2} \mathrm{O}\right]$ $\left(250,450,650\right.$, and $850 \mathrm{mg} \cdot \mathrm{kg}^{-1}$ soil $)$ were used in separate treatments. The clay soil used in this study was placed in plastic pots $40 \mathrm{~cm}$ in diameter with $9 \mathrm{~kg}$ of air-dried soil per pot, sprinkled with solutions of the aforementioned concentrations of metals and incubated for $60 \mathrm{~d}$ before being planted outdoors under a waterproof tarpaulin. Soil without heavy metal contamination served as a negative control.

Pot experiments. Homogeneous 3-monthold plants were transplanted to previously prepared plastic pots (one transplant per pot) on 1 May 2015. The experiment consisted of 13 treatments (three heavy metals $\times$ four concentrations and the negative control) with three replicates and three plants per replicate; therefore, nine plants were used for each treatment. The plants were placed in an open field after planting and were irrigated with tap water using 10-L watering cans to reach field capacity when required. The experiment continued for 27 months.

Soil analysis. Soil analysis was performed before and after completion of the experiment (Table 1). Both physical and chemical analyses were performed; the particle size distribution was analyzed using a hydrometer method (Gee and Balder, 1986) before planting only. The soil had a clay-like texture consisting of $24.03 \%$ sand, $22.92 \%$ silt, and $50.05 \%$ clay. Soil $\mathrm{pH}$ was measured in a $1: 1$ ratio (soil: deionized water suspension) using a calibrated $\mathrm{pH}$ meter 3510 (Jenway, Staffordshire, UK). Soil salinity [electrical conductivity (EC)] was measured in a 1:5 ratio (soil: deionized water) using an EC Meter (MI 170; Italy). Soluble ions in saturated extracts were measured according to the methods of Jackson (1973). Total carbonate was determined using a volumetric calcimeter (Nelson and Sommers, 1996). Organic matter content was determined using the dichromate oxidation method (Nelson and Sommers, 1996). Available nitrogen $\left(\mathrm{NH}_{4}^{+}\right)$was determined using the micro Kjeldahl method (Bremner and Mulvaney, 1982), and available phosphorus $\left(\mathrm{P}_{2} \mathrm{O}_{5}{ }^{-}\right)$was determined (Olsen and Sommers 1982). Calcium $\left(\mathrm{Ca}^{++}\right)$and magnesium $\left(\mathrm{Mg}^{++}\right)$ were also measured (Jackson, 1973). The concentrations of cadmium $\left(\mathrm{Cd}^{++}\right)$, copper $\left(\mathrm{Cu}^{++}\right)$, and lead $\left(\mathrm{Pb}^{++}\right)$were quantified using an atomic absorption spectrophotometer (Page et al., 1982). Sodium $\left(\mathrm{Na}^{+}\right)$and potassium $\left(\mathrm{K}^{+}\right)$were extracted according to the methods described by Black (1965), and concentrations were determined using a Flame photometer PFP7 (Jenway, Staffordshire, UK). Chloride $\left(\mathrm{Cl}^{-}\right)$was determined by titration with a standard solution of silver nitrate (Jackson, 1973).

Variables measurements. At the end of the experiment on 1 Aug. 2017, six samples (plants) from each treatment (for three replicates) were chosen randomly to determine the following growth parameters: plant height (measured from the medium surface to the shoot apex); number of branches per plant; stem diameter (measured $5 \mathrm{~cm}$ from the soil surface); leaf area using a C1-202 laser area meter (CID Bio-Science, Camas, WA); fresh and dry weights of vegetative growth and roots (recorded after drying in oven at $60{ }^{\circ} \mathrm{C}$ for $48 \mathrm{~h}$ ); and root lengths (the longest root). The degree of greenness was measured on the fifth leaf from the apical meristem using a portable leaf chlorophyll meter (SPAD-501; Minolta Corp., Osaka, Japan) according to the methodology described by Markwell et al. (1995).

Biochemical assays of antioxidant enzyme activities. To determine antioxidant enzyme activities, $0.5 \mathrm{~g}$ of fully expanded young leaves were homogenized in liquid nitrogen with $3 \mathrm{~mL}$ of extraction buffer [50 mM TRIS buffer ( $\mathrm{pH}$ 7.8) containing $1 \mathrm{~mm}$ EDTA-Na2 and $7.5 \%$ polyvinylpyrrolidone)] using a prechilled mortar and pestle. The homogenate was filtered through four layers of cheesecloth and centrifuged at $12,000 \mathrm{rpm}$ for $20 \mathrm{~min}$ at $4{ }^{\circ} \mathrm{C}$. The supernatant, which was re-centrifuged at $12,000 \mathrm{rpm}$ for $20 \mathrm{~min}$ at $4{ }^{\circ} \mathrm{C}$, was used for the total soluble enzyme activity assay using an ultraviolet-160A spectrophotometer (Shimadzu, Japan).

Catalase assay. Catalase (CAT; EC 1.11.1.6) activity was measured by following the consumption of $\mathrm{H}_{2} \mathrm{O}_{2}$ at $240 \mathrm{~nm}$ (Aebi, 1984). A total of $1 \mathrm{~mL}$ of the reaction mixture contained $20 \mu \mathrm{g}$ total protein, $50 \mathrm{~mm}$ sodium phosphate buffer $(\mathrm{pH} 7.0)$, and $10 \mathrm{mM} \mathrm{H}_{2} \mathrm{O}_{2}$. The reaction was initiated by adding the protein extract. For each measurement, the blank corresponded to the absorbance of the mixture at time zero, and the actual reading corresponded to the absorbance after $1 \mathrm{~min}$. One unit of CAT activity was defined as a 0.01 decrease in absorbance at $240 \mathrm{~nm} / \mathrm{mg}$ of protein $/ \mathrm{min}$.

Polyphenol oxidase assay. Polyphenol oxidase (PPO; EC 1.10.3.1) activity was determined according to the method described by Malik and Singh (1980). The reaction mixture contained $3.0 \mathrm{~mL}$ of 
Table 1. Chemical analysis of the soil used for growth of Salix mucronata before plantation and 27 months after plantation.

\begin{tabular}{|c|c|c|c|c|c|c|c|c|c|c|c|c|c|c|}
\hline \multirow[b]{3}{*}{ Parameter } & \multirow{3}{*}{$\begin{array}{l}\text { Soil before } \\
\text { plantation }\end{array}$} & \multicolumn{13}{|c|}{ Soil after plantation (Treatments $\mathrm{mg} \cdot \mathrm{kg}^{-1}$ soil) } \\
\hline & & \multirow[b]{2}{*}{ Control } & \multicolumn{4}{|c|}{ Cadmium } & \multicolumn{5}{|c|}{ Copper } & \multicolumn{3}{|c|}{ Lead } \\
\hline & & & 20 & 40 & 60 & 80 & 50 & 100 & 150 & 200 & 250 & 450 & 650 & 850 \\
\hline$\overline{\mathrm{pH}}$ & 7.84 & 7.84 & 7.82 & 7.82 & 7.81 & 7.79 & 7.84 & 7.83 & 7.81 & 7.81 & 7.80 & 7.82 & 7.77 & 7.78 \\
\hline $\mathrm{EC}\left(\mathrm{dS} \cdot \mathrm{m}^{-1}\right)$ & 3.30 & 2.36 & 4.38 & 4.56 & 4.75 & 5.00 & 3.38 & 4.69 & 4.79 & 4.87 & 3.44 & 3.63 & 4.06 & 4.69 \\
\hline $\mathrm{CaCo}_{3}(\%)$ & 3.26 & 3.15 & 3.12 & 3.19 & 3.19 & 3.19 & 3.16 & 3.19 & 3.18 & 25.17 & 2.89 & 3.12 & 3.17 & 3.17 \\
\hline Organic matter $(\%)$ & 1.31 & 1.24 & 1.25 & 1.27 & 1.28 & 1.28 & 1.27 & 1.27 & 1.28 & 1.28 & 1.26 & 1.27 & 1.27 & 1.27 \\
\hline \multicolumn{15}{|c|}{ Soluble cations $\left(\mathrm{meq} \cdot \mathrm{L}^{-1}\right)$} \\
\hline $\mathrm{Ca}^{++}$ & 7.71 & 5.56 & 11.35 & 12.21 & 13.46 & 15.53 & 7.92 & 11.80 & 13.89 & 13.85 & 7.98 & 9.46 & 11.33 & 12.71 \\
\hline $\mathrm{Mg}^{++}$ & 4.82 & 3.97 & 8.41 & 8.52 & 8.69 & 9.43 & 4.90 & 9.80 & 8.80 & 9.52 & 4.99 & 5.20 & 7.09 & 9.55 \\
\hline $\mathrm{Na}^{+}$ & 20.12 & 13.92 & 22.54 & 23.17 & 23.92 & 23.38 & 20.14 & 23.77 & 23.33 & 23.42 & 20.92 & 20.67 & 20.87 & 22.96 \\
\hline $\mathrm{K}^{+}$ & 0.35 & 0.17 & 1.42 & 1.70 & 1.63 & 1.66 & 0.82 & 1.53 & 1.88 & 1.91 & 0.59 & 0.97 & 1.31 & 1.68 \\
\hline \multicolumn{15}{|c|}{ Soluble anions $\left(\mathrm{meq} \cdot \mathrm{L}^{-1}\right)$} \\
\hline $\begin{array}{l}\mathrm{Cl}^{-} \\
\mathrm{CO}_{3}^{-}\end{array}$ & 19.73 & 13.16 & 23.44 & 24.20 & 24.44 & 25.92 & 20.20 & 23.20 & 23.44 & 24.47 & 21.68 & 21.44 & 22.44 & 22.68 \\
\hline $\mathrm{HCO}_{3}^{-}$ & 2.50 & 2.35 & 4.38 & 4.96 & 5.15 & 5.30 & 3.31 & 4.69 & 4.79 & 4.87 & 3.44 & 3.13 & 4.06 & 4.69 \\
\hline $\mathrm{SO}_{4}^{-}$ & 10.77 & 8.09 & 15.90 & 16.44 & 17.84 & 18.78 & 10.27 & 19.01 & 19.70 & 19.36 & 9.27 & 11.73 & 14.10 & 19.53 \\
\hline \multicolumn{15}{|c|}{ Available minerals $\left(\mathrm{mg} \cdot \mathrm{kg}^{-1}\right)$} \\
\hline $\mathrm{N}$ & 2.75 & 1.89 & 2.36 & 2.39 & 2.60 & 2.60 & 2.35 & 2.38 & 2.42 & 2.56 & 2.41 & 2.43 & 2.44 & 2.46 \\
\hline $\mathrm{P}$ & 3.51 & 2.45 & 2.43 & 2.48 & 2.98 & 3.11 & 2.62 & 2.64 & 3.23 & 3.33 & 2.73 & 2.83 & 2.85 & 3.06 \\
\hline $\mathrm{K}$ & 216 & 144 & 166 & 172 & 183 & 189 & 169 & 191 & 198 & 201 & 126 & 179 & 198 & 201 \\
\hline $\mathrm{Cd}$ & 00 & & 2.74 & 5.47 & 7.84 & 10.00 & & & & & & & & \\
\hline $\mathrm{Cu}$ & 3.6 & 1.87 & & & & & 5.08 & 9.59 & 16.48 & 28.21 & & & & \\
\hline $\mathrm{Pb}$ & 00 & & & & & & & & & & 10.85 & 13.2 & 19.28 & 25.61 \\
\hline
\end{tabular}

$\mathrm{Ca}=$ calcium $; \mathrm{Mg}=$ magnesium $; \mathrm{Na}=$ sodium $; \mathrm{K}=$ potassium $; \mathrm{N}=$ nickel $\mathrm{P}=$ phosphorus $\mathrm{Cd}=\mathrm{cadmium} ; \mathrm{Cu}=$ copper $; \mathrm{Pb}=$ lead.

buffered catechol solution $(0.01 \mathrm{M})$ freshly prepared in $0.1 \mathrm{M}$ phosphate buffer ( $\mathrm{pH} 6.0$ ). The reaction was initiated by adding $100 \mu \mathrm{L}$ of the crude enzyme extract. Changes in the absorbance at $495 \mathrm{~nm}$ were recorded at $30 \mathrm{~s}$ for $3 \mathrm{~min}$. Enzyme activity was expressed as an increase in the absorbance $\mathrm{min}^{-1} \cdot \mathrm{g}^{-1}$ fresh weight.

Peroxidase assay. Peroxidase (POD; EC 1.11.1.7) activity was determined according to the procedure proposed by Hammerschmidt et al. (1982). The reaction mixture consisted of $2.9 \mathrm{~mL}$ of a $100-\mathrm{mm}$ sodium phosphate buffer [pH 6.0 containing $0.25 \%$ $(\mathrm{v} / \mathrm{v})$ guaiacol (2-methoxy phenol) and $100 \mathrm{~mm} \mathrm{H}_{2} \mathrm{O}_{2}$ ]. The reaction was started by adding $100 \mu \mathrm{L}$ of crude enzyme extract. Changes in absorbance at $470 \mathrm{~nm}$ were recorded at 30-s intervals for $3 \mathrm{~min}$. Enzyme activity was expressed as an increase in the absorbance $\min ^{-1} \cdot \mathrm{g}^{-1}$ fresh weight.

Electrolyte leakage. Measurements were performed as described by Szalai et al. (1996), with some modifications. Twenty leaf discs $\left(1 \mathrm{~cm}^{2}\right)$ were placed individually into flasks containing $25 \mathrm{~mL}$ of deionized water (Milli-Q 50, Millipore, Bedford, MA). Flasks were shaken for $20 \mathrm{~h}$ at an ambient temperature to facilitate electrolyte leakage from injured tissues. Initial EC measurements were recorded for each vial using an Acromet AR20 EC meter (Fisher Scientific, Chicago, IL). Flasks were then immersed in a hot water bath (Fisher Isotemp, Indiana, PA) at $80{ }^{\circ} \mathrm{C}$ $\left(176^{\circ} \mathrm{F}\right)$ for $1 \mathrm{~h}$ to induce cell rupture. The vials were again placed on the Innova 2100 platform shaker for $20 \mathrm{~h}$ at $21^{\circ} \mathrm{C}\left(70{ }^{\circ} \mathrm{F}\right)$. Final conductivity was measured for each flask. The percentage of electrolyte leakage for each bud was calculated as the initial conductivity/final conductivity $\times 100$.

Chemical composition. Plant samples (leaves, stems, and roots) were oven-dried at $80^{\circ} \mathrm{C}$ for $24 \mathrm{~h}$. Dry samples were ground to obtain a homogenous powder in a metal-free mill (IKa-Werke, M 20 Germany). Concentrated sulfuric acid $(95 \%, 5 \mathrm{~mL})$ was added to the sample $(0.2 \mathrm{~g})$, and the mixture was heated for $10 \mathrm{~min}$ on a sand hotplate. Then, $0.5 \mathrm{~mL}$ of perchloric acid was added, and heating was continued until a clear solution was obtained. The solution was left to cool before it was filtered and diluted to $50 \mathrm{~mL}$ with distilled water (Evenhuis and de Waard, 1980). The digested samples were prepared for nitrogen measurements (N\% using a modified micro-Kjeldahl method as described by Chemists and Horwitz, 1990). Phosphorus ( $\mathrm{P} \%)$ was extracted according to the methods described by Murphy and Riley (1962) and detected by colorimetrically in a spectrophotometer (GT $80^{+}$, UK). Potassium $(\mathrm{K} \%)$ was extracted according to the methods described by Cottenie et al. (1982) and detected using an atomic absorption spectrophotometer (Avanta E; GBC, Victoria, Australia). The total carbohydrate percentage in leaves was determined according to the methods described by Herbert et al. (1971). In addition, $\mathrm{N}, \mathrm{P}$, and $\mathrm{K}$ leaf uptake ( $\mathrm{mg}$ ) were calculated as described for the percentage of $\mathrm{N}, \mathrm{P}$, and $\mathrm{K}$ in dry leaves. The $\mathrm{Cd}, \mathrm{Cu}$, and $\mathrm{Pb}$ concentrations ( $\mathrm{mg} \cdot \mathrm{kg}^{-1}$ dry weight) were determined using the methods of Page et al. (1982) in different plant parts (leaves, stems, and roots) using atomic absorption spectrophotometry (Avanta E; GBC).

Determination of the phytoextraction potential of $S$. mucronata for removing $C d$, $\mathrm{Cu}$, and $\mathrm{Pb}$ from contaminated soil. The bioconcentration factor was determined using the following formula:

Bioconcentration factor $(\mathrm{BCF})=$

Metal concentration in the plant organ $\left(\mathrm{mg} \cdot \mathrm{kg}^{-1} \mathrm{D}\right.$.W. Metal concentration in the soil $\left(\mathrm{mg} \cdot \mathrm{kg}^{-1}\right.$ soil D.W.)

The $\mathrm{Cd}, \mathrm{Pb}$, and $\mathrm{Cu}$ concentrations per $\mathrm{kg}$ of soil were calculated (regardless of the calculated $\mathrm{BCF}$ ) as follows: added $\mathrm{Cu}$ con- centration $/ \mathrm{kg}$ soil in treatment $+\mathrm{Cu}$ concentration $/ \mathrm{kg}$ in soil before contamination. Depending on the BCF values, the accumulation efficiency was estimated as one of four groups: intensive, $\mathrm{BCF}>1$; medium, $\mathrm{BCF}=$ $1-0.1$; weak, $\mathrm{BCF}=0.1-0.01$; and no accumulation, $\mathrm{BCF}=0.01-0.001$ (KabataPendias and Pendias, 1999)

Translocation factor $\%=$

Metal content in the shoots $\left(\mathrm{mg} \cdot \mathrm{kg}^{-1}\right.$ D.W. $) \times 100$ Metal content in the roots $\left(\mathrm{mg} \cdot \mathrm{kg}^{-1} \mathrm{D} . \mathrm{W}\right.$.)

The TF\% was calculated to estimate the metal ion transport efficiency from the roots to aerial plant organs (Maiti and Jaiswal, 2008), whereas shoots were considered equivalent to leaves and stems.

The biomass tolerance index $\left(\mathrm{TI}_{\mathrm{b}}\right)$ was calculated to estimate the resistance of $S$. mucronata to $\mathrm{Cd}, \mathrm{Cu}$, and $\mathrm{Pb}$ phytoextraction. According to Wilkins (1978), there are three values: $\mathrm{TI}_{\mathrm{b}}<1$, indicating a net decrease in biomass and stressed conditions of plants; $\mathrm{TI}_{\mathrm{b}}=1$, indicating no difference relative to control treatment; and $\mathrm{TI}_{\mathrm{b}}>1$, indicating a net increase in biomass and correct plant development.

Statistical analysis. The experiment used a completely randomized design. Data were subjected to an analysis of variance using the SAS program (version 6.12; SAS Institute Inc., Cary, NC). The mean separations were performed using Duncan's multiple range testing method, and significance was determined at $P \leq 0.05$

\section{Results and Discussion}

Soil analysis and contamination. A physiochemical analysis of the soil used for the growth of $S$. mucronata demonstrated that the texture was clay-like and had an organic matter level of 1.31 and a $\mathrm{pH}$ level of 7.84 (Table 1). In addition, changes in organic matter and $\mathrm{CaCO}_{3}$ content before and after 


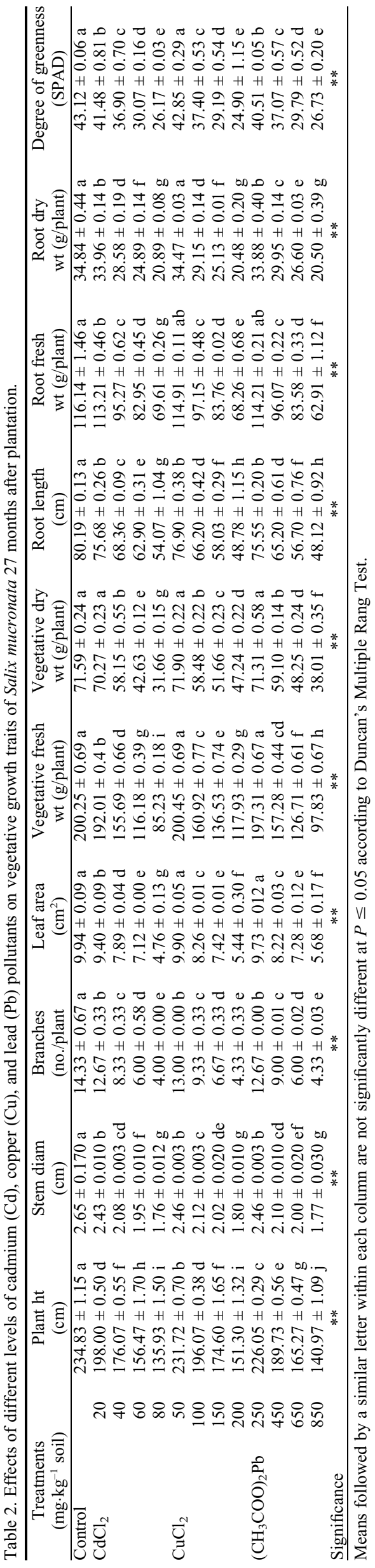

planting were limited. Conversely, cation and anion concentrations increased after planting using the $\mathrm{Cd}, \mathrm{Cu}$, and $\mathrm{Pb}$ treatments, except for control treatments, which were decreased. Regardless of the treatments, the changes in $\mathrm{pH}$ values were slight, but we noted a slight decrease in EC values after control planting. However, EC values increased in soil contaminated with heavy metals to $5 \mathrm{dS} \cdot \mathrm{m}^{-1}$ at 80 $\mathrm{mg} \cdot \mathrm{kg}^{-1} \mathrm{CdCl}_{2}$. The available concentrations of $\mathrm{N}, \mathrm{P}$, and $\mathrm{K}$ decreased in the control soil after planting compared with the soil before planting.

In contrast, the available concentrations of $\mathrm{N}, \mathrm{P}$, and $\mathrm{K}$ were only slightly decreased in soil contaminated with high heavy metal concentrations. Furthermore, $\mathrm{Cd}, \mathrm{Cu}$, and $\mathrm{Pb}$ concentrations were deceased after planting relative to their concentrations before planting. There were negligible changes in $\mathrm{pH}$ values with the treatments used in this study. Accordingly, Vysloužilová et al. (2006) found that soil $\mathrm{pH}$ did not differ among rhizobox compartments of $\mathrm{Cd}-, \mathrm{Pb}-$, and Zn-polluted soil under Salix $\times$ robens clones. Soil characteristics such as $\mathrm{pH}$, organic matter (O.M.), and cation exchange capacity were positively correlated with $\mathrm{Cu}$ retention (King, 1988) and $\mathrm{Cd}$ and $\mathrm{Pb}$ retention (Jopony and Young, 1994). The increased EC values may be due to the addition of metals, resulting in increased cations and anions. However, larger quantities of ions and soluble salts have resulted in increased EC values in industrial effluent-treated soil samples (Sharma and Raju, 2013). Additionally, the reduction in available $\mathrm{N}, \mathrm{P}, \mathrm{K}$, soluble cations, and $\mathrm{Cd}, \mathrm{Cu}$, and $\mathrm{Pb}$ concentrations after planting may refer to the uptake by plant roots or the loss to irrigation water. It is known that plants were growing in soil with a $\mathrm{pH}$ of 7.84; at this $\mathrm{pH}$, the uptake of essential nutrients by roots, especially $\mathrm{N}, \mathrm{P}$, $\mathrm{K}, \mathrm{Mg}$, and $\mathrm{Zn}$, among others, is poor. These nutrients are extremely important for many components such as carbohydrates, proteins, amino acids, phospholipids, and energy components. In addition, $\mathrm{Cd}$ and $\mathrm{Pb}$ negatively impact the permeability of the plasma membrane (Pourrut et al., 2011; Sharma et al., 2010).

Effect of heavy metal-contaminated soil on vegetative growth. Using different concentrations of $\mathrm{Cd}, \mathrm{Cu}$, and $\mathrm{Pb}$ significantly reduced most vegetative traits compared with control plants (Tables 2). The highest values for plant height, stem diameter, and the number of branches were reported for the negative control treatment group as 234.83 $\mathrm{cm}, 2.65 \mathrm{~cm}$, and 14.33, respectively. Leaf area and vegetative fresh and dry weight exhibited the same trend for all treatments, showing a decrease with increasing heavy metal concentrations. Additionally, the values of root lengths, root fresh and dry weights, and greenness degrees were significantly reduced for all $\mathrm{Cd}, \mathrm{Cu}$, and $\mathrm{Pb}$ levels compared with controls, except $50 \mathrm{mg} \cdot \mathrm{kg}^{-1} \mathrm{CuCl}_{2}$ and $250 \mathrm{mg} \cdot \mathrm{kg}^{-1} \mathrm{~Pb}$ acetate. Therefore, the reduction in root parameters was parallel to increasing heavy metal levels in the soil. The results showed that low heavy metal concentrations had the same significant effect as the controls on most traits. In addition, 50 $\mathrm{mg} \cdot \mathrm{kg}^{-1} \mathrm{CuCl}_{2}$ and $250 \mathrm{mg} \cdot \mathrm{kg}^{-1} \mathrm{~Pb}$ acetate had the same effect on all traits except plant height and degree of greenness.

Conversely, high concentrations of heavy metals had negative effects on all studied traits. Our findings indicated that vegetative growth and root traits were drastically inhibited, especially with medium and high heavy metal concentrations. Tauqeer et al. (2016) revealed that root fresh and dry weights of Alternanthera bettzickiana significantly decreased at $0.225 \mathrm{mg} \cdot \mathrm{L}^{-1} \mathrm{Cd}$ and $0.414 \mathrm{mg} \cdot \mathrm{L}^{-1} \mathrm{~Pb}$. Additionally, Cd stress deleteriously affects the photosynthetic rate and intracellular $\mathrm{CO}_{2}$ concentration and can interfere with photosynthetic pigments by substituting $\mathrm{Mg}^{2+}$ ions with $\mathrm{Cd}^{2+}$ ions in chlorophyll molecules, producing much lower fluorescence quantum yields compared with magnesium chlorophylls (Jing et al., 2005). These two toxic effects reduce the production of chlorophyll and, consequently, photosynthesis, which can lead to senescence and cell death (Santos et al., 2010). Vegetative trait values gradually decreased with the increasing concentrations of each element in the soil. However, there was no plant lethality at any of the tested concentrations of the elements. Some toxic effects appeared on the adult leaves, such as yellow coloration and drying of the leaf edges after treatments with high heavy metal concentrations. The reduction in growth and abscission of leaves were observed in Willow Tangio ( $S$. mastudana $\times$ $S$. alba) when grown in soil containing $0.6-$ $60.6 \mu \mathrm{g} \cdot \mathrm{g}^{-1} \mathrm{Cd}$ (Robinson et al., (2000). Additionally, the total leaf area of Willow clones was affected by $38.5 \mathrm{mg} \cdot \mathrm{L}^{-1} \mathrm{Cd}$ sulfate (Zacchini et al., 2009) and 0.19 $\mathrm{mg} \cdot \mathrm{L}^{-1} \mathrm{Cu}$ in $S$. viminalis (Gasecka et al., 2012). In the present study, high concentrations of heavy metals suppressed root development of $S$. mucronata. Moreover, Yuan et al. (2013) indicated that excess $\mathrm{Cu}$ in the root zone and more uptake by plant roots have hazardous effects on elongation and meristem zones because they alter auxin distribution, which is responsible for $\mathrm{Cu}$ mediated inhibition of primary root elongation. In addition, $\mathrm{Pb}$ toxicity leads to the inhibition of photosynthesis, oxidative stress, DNA damage, and defects in mitosis (Kupper, 2017). All these effects lead to reduced growth rates of the aerial or root parameters and leaf chemical composition. These toxicity symptoms were increased in the youngest plant at the beginning of the experiment, but they were decreased in older plants at the end of the experiment. Therefore, we inferred that older $S$. mucronata plants had greater tolerance for heavy metals compared with younger plants. Tolerance increased with increasing plant age, and some toxic symptoms decreased in older plants $(\mathrm{Tu}$ et al., 2004).

Effects of heavy metal-contaminated soil on enzyme activities and electrolyte leakage. Significantly higher activities of CAT, PPO, 
and POD were observed in plant leaves grown on soil contaminated with different $\mathrm{Cd}, \mathrm{Cu}$, and $\mathrm{Pb}$ levels compared with control plants (Fig. 1a-c). The results indicated that $40 \mathrm{mg} \cdot \mathrm{kg}^{-1} \mathrm{CdCl}_{2}, 100 \mathrm{mg} \cdot \mathrm{kg}^{-1} \mathrm{CuCl}_{2}$, and $450 \mathrm{mg} \cdot \mathrm{kg}^{-1} \mathrm{~Pb}$ acetate induced a significant increase in antioxidant enzyme activities compared with other treatments and the negative control treatment. The maximum activity of PPO and POD was observed in 100 $\mathrm{mg} \cdot \mathrm{kg}^{-1} \mathrm{CuCl}_{2}$ and $450 \mathrm{mg} \cdot \mathrm{kg}^{-1} \mathrm{~Pb}$ acetate treatments, respectively, whereas the highest
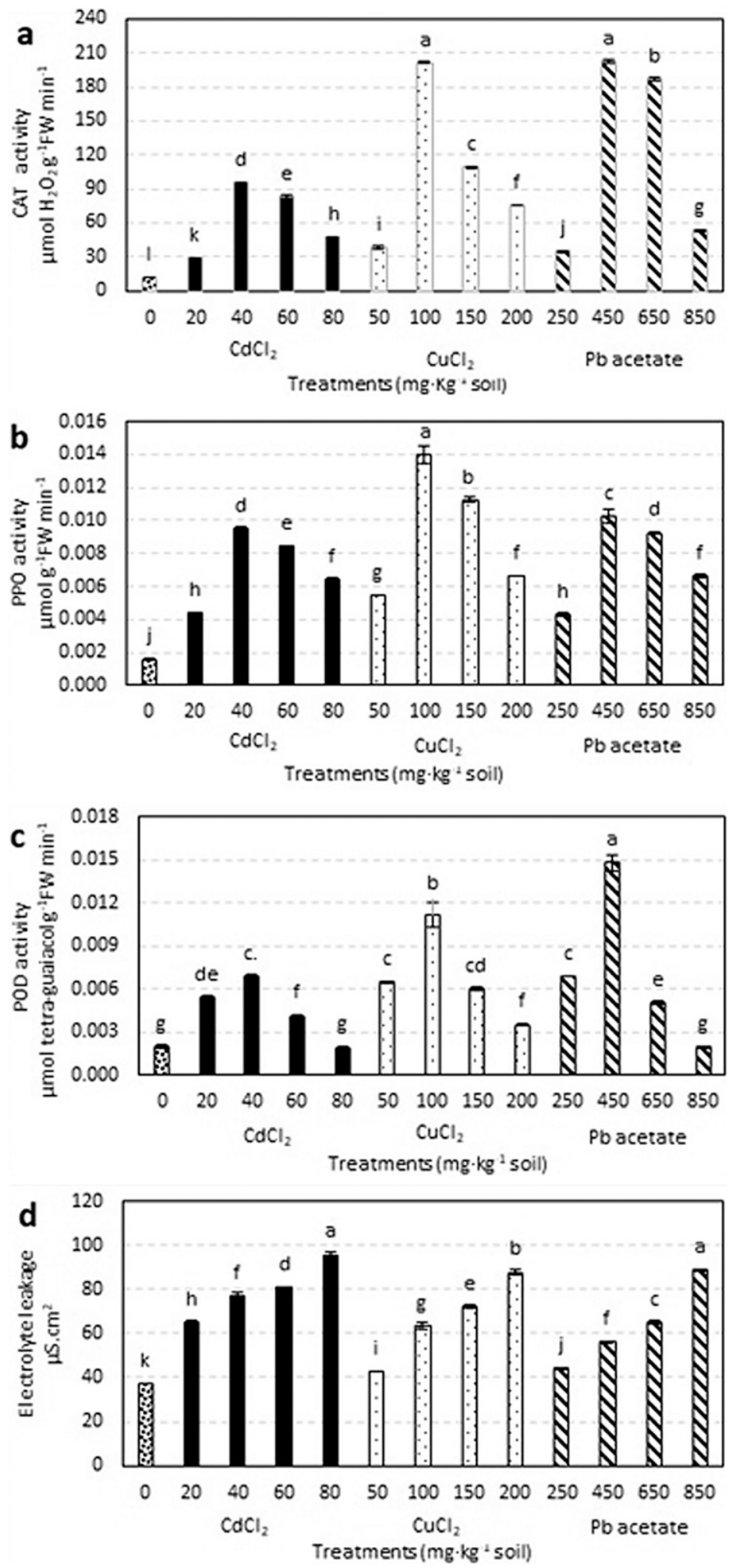

Fig. 1. Effects of different levels of cadmium $(\mathrm{Cd})$, copper $(\mathrm{Cu})$, and lead $(\mathrm{Pb})$ on antioxidant enzyme activity and electrolyte leakage of $S$. mucronata. (A) Catalase, (B) polyphenol oxidase, (C) peroxidase, and (D) electrolyte leakage (similar letters within a figure are not significantly different at $P \leq 0.05$ according to Duncan's multiple range test).

value of CAT activity was recorded for 100 $\mathrm{mg} \cdot \mathrm{kg}^{-1} \mathrm{CuCl}_{2}$ and $450 \mathrm{mg} \cdot \mathrm{kg}^{-1} \mathrm{~Pb}$ acetate. Previous reports confirmed the relationship between heavy metal-contaminated soil and oxidative stress in Euplotes crassus for $\mathrm{Cu}$, $\mathrm{Pb}$, and $\mathrm{Zn}$ (Kim et al., 2011) and in Nasturtium officinale for $\mathrm{Cr}, \mathrm{Cu}$, and $\mathrm{Cd}$ (Ercan et al., 2018). According to these studies, the maximum antioxidant enzyme-coding genes (Ec-GR, Ec-GPx, and Ec-GST theta) were observed in E. crassus, and catalase, superoxide dismutase, and increased levels of malondialdehyde in $N$. officinale were observed with increasing heavy metal concentrations. Biosynthesis of several cellular biomolecules is the primary mechanism of tolerating or neutralizing metal toxicity. This includes the induction of many components such as amino acids, organic acids, hormones, and phenolic compounds (Viehweger, 2014). Previous studies have mentioned that increased antioxidant enzyme activity in $N$. officinale has an important role in alleviating the toxicity of $\mathrm{Cr}, \mathrm{Cu}$, and $\mathrm{Cd}$ (Ercan et al., 2018).

In contrast, the aforementioned strategies are not sufficient to restrain metal poisoning, and the equilibrium of the cellular redox system in plants is negatively affected, leading to increased induction of reactive oxygen species (Mourato et al., 2012). To mitigate the harmful effects of free radicals, plant cells have developed an antioxidant defense mechanism composed of enzymatic antioxidants such as CAT (Sharma et al., 2012). Increased CAT, PPO, and POD activities occur in the presence of low heavy metals concentrations; these decrease when high levels are encountered (but still higher than the control). This phenomenon was observed by Zou et al. (2017) in S. matsudana treated with $\mathrm{Cd}$ at 1.124 $\mathrm{mg} \cdot \mathrm{L}^{-1}$ as a low concentration and 11.24 $\mathrm{mg} \cdot \mathrm{L}^{-1}$ as a high concentration. Emamverdian et al. (2018) observed a similar effect in Indocalamas latifolius treated with $\mathrm{Cu}, \mathrm{Pb}$, and $\mathrm{Zn}$ at four different concentrations $(0$, 500,1000 , and $2000 \mathrm{mg} \cdot \mathrm{kg}^{-1}$ )

Concerning the results of EL, it should be noted that with increasing concentrations of each heavy metal in the soil, the value of EL is significantly increased (Fig. 1D). Overall, the maximum significant values of $\mathrm{EL}$ resulted from treatment with $80 \mathrm{mg} \mathrm{CdCl}_{2}$ and $850 \mathrm{mg} \mathrm{Pb}$ acetate compared with other heavy metal concentrations. The lowest EL value was found in the control plants. This finding suggests that levels of heavy metals have negative impacts on cell membranes. Ion leakage is a well-known parameter for the evaluation of oxidative damage to cell membranes (Liu et al., 2008) that expresses membrane dysfunction as the increase in permeability and electrolyte leakage from the cell. Membrane damage can be inferred from an increase in EL because of $\mathrm{Cu}$ (Liu et al., 2004); additionally, increased Cd levels markedly increase EL, along with enhanced activities of antioxidant enzymes (Ahmad et al., 2016). Tauqeer et al. (2016) revealed that with lower $\mathrm{Cd}$ and $\mathrm{Pb}$ levels, POD and CAT activities increased, whereas 


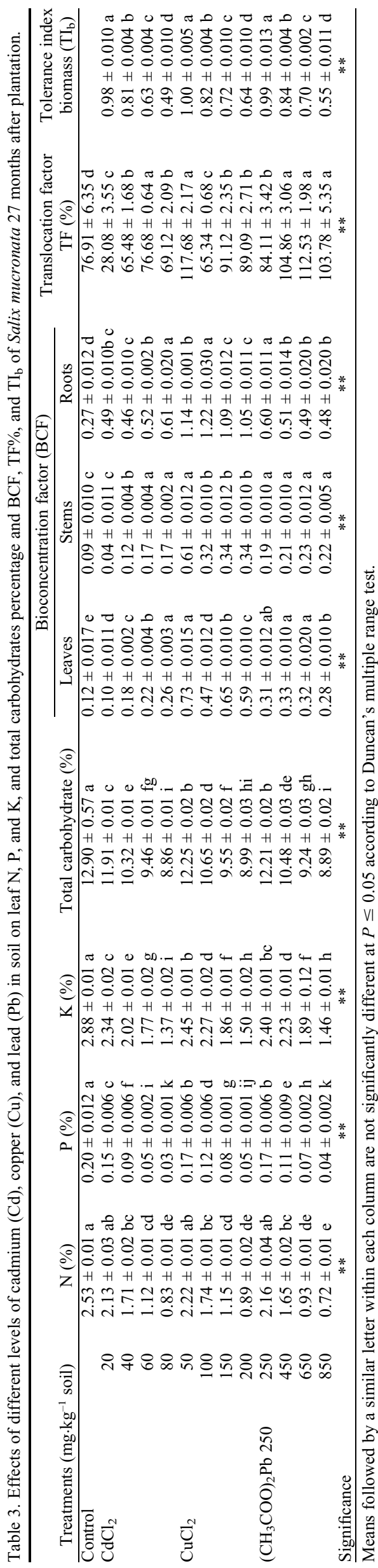

with higher levels the opposite occurred, and $\mathrm{EL}$ increased with increasing $\mathrm{Cd}$ and $\mathrm{Pb}$ levels.

Effects of heavy metal-contaminated soil on the chemical analysis of leaves. N, P, K, and total carbohydrate percentages of plants grown on the heavy metal-contaminated soil were significantly lower than those of controls (Table 3). The impact of applied $\mathrm{Cd}, \mathrm{Cu}$, and $\mathrm{Pb}$ concentrations on these parameters showed a similar decreasing trend in the presence of increasing heavy metal concentrations. In contrast, the $\mathrm{N} \%$ of plants grown in soil with a low heavy metal content was not significantly different from that of control plants. In addition, our results showed that the reduction in values of $\mathrm{N} \%$ depended on the level of each metal in the soil. Gasecka et al. (2012) reported that the inhibition of carbohydrate transport to different organs resulted from the high $\mathrm{Cu}$ accumulation in the roots of $S$. viminalis and was similarly lower in leaves and shoots. Furthermore, Cd has a negative impact on the permeability of the plasma membrane, thus interfering with nutrient uptake (Sarwar et al., 2010). Additionally, lead accumulation in plant tissues reacts with the phosphate groups of ADP or ATP and replaces essential ions, thus impairing the uptake of essential elements such as $\mathrm{Mg}$ and $\mathrm{Fe}$, and induces $\mathrm{CO}_{2}$ deficiency resulting from stomatal closure (Pourrut et al., 2011). Growth inhibition or stimulation of willow species or clones is dependent on metal concentrations in the nutrient solution (Krajcarova et al., 2016). Drzewiecka et al. (2017) revealed that significantly decreased growth rate values of Salix purpurea $\times S$. viminalis in relation to control plants were noted for all $\mathrm{Cu}^{2+}$-treated plants, as was a strong affirmation of negative effects of $\mathrm{Cu}^{2+}$ in the root system. Overall, foliage element concentrations differ according to their concentration in soil or soil chemistry and according the plant species or clones (Mosseler and Major, 2017).

Effects of heavy metal-contaminated soil on $\mathrm{Cd}, \mathrm{Cu}$, and $\mathrm{Pb}$ concentrations in plant parts. $\mathrm{Cd}, \mathrm{Cu}$, and $\mathrm{Pb}$ levels in plant tissues grown on heavy metal-contaminated soil were significantly higher than those in control plant tissues (Fig. 2A-C). The metal content in the different plant parts gradually increased with increased levels of the corresponding metal in the soil. The results indicated that the highest significant metal concentrations in the plant parts were recorded for the highest concentrations of each heavy metal used. The content of $\mathrm{Cd}$, $\mathrm{Cu}$, and $\mathrm{Pb}$ in the plant parts was in the order of roots $>$ leaves $>$ stems. Our previous results indicated that the content of $\mathrm{Cd}, \mathrm{Cu}$, and $\mathrm{Pb}$ increased with increasing levels in the root zone. In this regard, Mleczek et al. (2013) found a general increase in $\mathrm{Cu}$ accumulation in $S$. viminalis organs with increased $\mathrm{Cu}$ concentrations in the medium. Additionally, S. polaris organs treated with Cd have shown different concentrations between plant parts (Krajcarova et al., 2016). Our results confirmed that the concentrations of $\mathrm{Cd}, \mathrm{Cu}$, and $\mathrm{Pb}$ were higher in roots than in aerial parts. Tang et al. (2017) reported $\mathrm{Pb}$ levels in all $S$. mastudana organs with the following order: roots $>$ cutting $>$ twigs $>$ leaves. Therefore, $S$. mucronata roots accumulated much more $\mathrm{Cd}, \mathrm{Cu}$, and $\mathrm{Pb}$ than the leaves; in this case, the risk of contamination of the wider environment through leaf fall can be considered minimal. Therefore, these data suggest that $S$. mucronata is a suitable alternative to deciduous hyperaccumulators

Relationship between metal concentrations in soil and concentrations in plant organs. The phytoextraction efficiency of plant organs for $\mathrm{Cd}, \mathrm{Cu}$, and $\mathrm{Pb}$ is dependent on soil concentrations (Table 3 ). The estimated $\mathrm{BCF}$ indicated that the majority of $\mathrm{Cd}, \mathrm{Cu}$, and $\mathrm{Pb}$ accumulations in plant organs were considered medium $(\mathrm{BCF}=1-0.1)$. Conversely, the $\mathrm{Cd}$ content in leaves and stems on treatment with $20 \mathrm{mg} \cdot \mathrm{kg}^{-1} \mathrm{CdCl}_{2}$ was estimated as weak $(\mathrm{BCF}=0.1-0.01)$, and the $\mathrm{Cu}$ content in roots was estimated as intensive $(\mathrm{BCF}>1)$. In general, $\mathrm{BCF}$ values were higher in roots, followed by leaves and stems, in $\mathrm{Cd}$ contaminated, $\mathrm{Cu}$-contaminated, and $\mathrm{Pb}$ contaminated soil. The BCF values for plant organs are dependent on the type of metal ion and its concentration in the soil, as well as the plant organ. Kabata-Pendias and Pendias (1999) reported that in the majority of cases, BCF values for leaves, stems, and roots are medium (1-0.01) for Cd-contaminated, $\mathrm{Cu}-$ contaminated, and $\mathrm{Pb}$-contaminated soil, with some exceptions, especially BCF values of roots in $\mathrm{Cu}$-contaminated soil, which is estimated as intensive $(\mathrm{BCF}>1)$. Heavy metal mobility decreases with increasing soil $\mathrm{pH}$ ( $\mathrm{pH} \geq 8$ ) due to the precipitation of hydroxides and carbonates or the formation of the insoluble organic complex (Smith and Giller, 1992). Therefore, $\mathrm{BCF}<1$ for $\mathrm{Cd}$ and $\mathrm{Pb}$ indicated that $S$. mucronata selected these metals, whereas $\mathrm{BCF}<1$ for $\mathrm{Cu}$ indicated that $S$. mucronata is nonselective for $\mathrm{Cu}$ in contaminated soil. Accumulations of $\mathrm{Cd}, \mathrm{Cu}$, and $\mathrm{Pb}$ are dependent on their concentrations in the root zone, soil $\mathrm{pH}$, and plant organs Moreover, Dos Santos Utmazian et al. (2007) revealed that willow growth and phytoextraction efficiency were significantly dependent on the planted species, and that there were differences in plant biomass, metal tolerance, and metal phytoextraction of willow clones. In addition, BCF values of different organs (leaf, bark, shoots, and roots) of $S$. viminalis in $\mathrm{Cu}$ concentrations of different $\mathrm{Ca} / \mathrm{Mg}$ ratios were estimated as weak in most cases and as moderate in some cases, particularly in roots (Mleczek et al., 2013).

$\mathrm{The} \mathrm{TF} \%$ from the roots to the aerial parts was significantly increased with increasing $\mathrm{Cd}$ and $\mathrm{Pb}$ concentrations in the soil until the (Table 3 ). In addition, the $\mathrm{TF} \%$ for $\mathrm{Cu}$ did not exhibit a clear trend with various concentrations of $\mathrm{Cu}$. However, the highest values of $\mathrm{TF} \%$ were $76.68 \%, 117.68 \%$, and $112.53 \%$ observed with $60 \mathrm{mg} \cdot \mathrm{kg}^{-1} \mathrm{Cd} \mathrm{Cl}_{2}$, $50 \mathrm{mg} \cdot \mathrm{kg}^{-1} \mathrm{CuCl}_{2}$, and $650 \mathrm{mg} \cdot \mathrm{kg}^{-1} \mathrm{~Pb}$ 

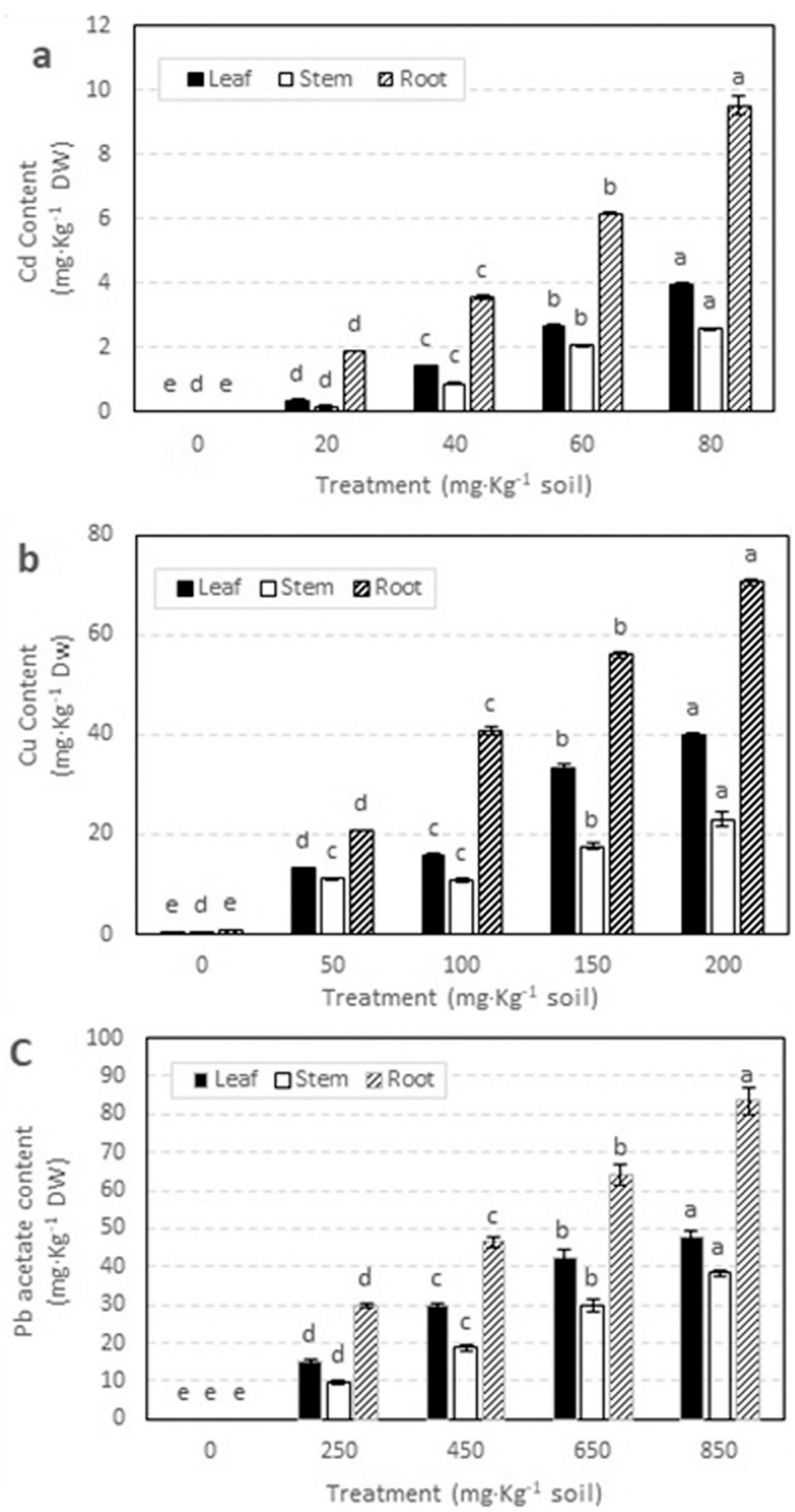

Fig. 2. Heavy metal contents in the leaf, stem, and roots of Salix mucronata. (A) Cadmium (Cd) content, (B) copper $(\mathrm{Cu})$ content, and $(\mathbf{C})$ lead $(\mathrm{Pb})$ content (similar letters within a figure are not significantly different at $P \leq 0.05$ according to Duncan's multiple range test). acetate, respectively. Based on these observations, $\mathrm{TF} \%$ values are dependent on the type of metal ion and its concentration in the root zone. The natural levels of free $\mathrm{Cd}$ and $\mathrm{Pb}$ can be highly influenced by cellular sequestration of these metals, which affects their movement throughout the plant (Niu et al., 2007). Our results indicate that $\mathrm{TF} \%$ values of $\mathrm{Cd}$ at different levels were not higher. Supporting this result, Lux et al. (2011) showed that the $\mathrm{TF} \%$ of $\mathrm{Cd}$ is often restricted due to the ability to create a $\mathrm{Cd}-$ phytoextraction complex by sequestration in the vacuole. Despite the excessive Cd concentrations in soil and even in the $S$. polaris leaves and stems that were identified (Krajcarova et al., 2016), the plant can activate some protection mechanisms against the excessive intake of $\mathrm{Cd}$, resulting in decreased $\mathrm{TF} \%$.

$\mathrm{TI}_{\mathrm{b}}$ values were significantly reduced with increasing $\mathrm{Cd}, \mathrm{Cu}$, and $\mathrm{Pb}$ concentrations in the soil (Table 3 ). Therefore, the highest values of $\mathrm{TI}_{\mathrm{b}}(0.98,1.00$, and 0.99$)$ were observed with $20 \mathrm{mg} \cdot \mathrm{kg}^{-1} \mathrm{CdCl}_{2}, 50 \mathrm{mg} \cdot \mathrm{kg}^{-1}$ $\mathrm{CuCl}_{2}$, and $250 \mathrm{mg} \cdot \mathrm{kg}^{-1} \mathrm{~Pb}$ acetate, respectively. Conversely, the lowest $\mathrm{TI}_{\mathrm{b}}$ values were $0.49,0.64$, and 0.55 for $80 \mathrm{mg} \cdot \mathrm{kg}^{-1}$ $\mathrm{CdCl}_{2}, 200 \mathrm{mg} \cdot \mathrm{kg}^{-1} \mathrm{CuCl}_{2}$, and $850 \mathrm{mg} \cdot \mathrm{kg}^{-1}$ $\mathrm{Pb}$ acetate, respectively. According to these data, $\mathrm{TI}_{\mathrm{b}}$ values were less than 1 for $\mathrm{Cd}, \mathrm{Cu}$, and $\mathrm{Pb}$ levels (a net decrease in biomass and stressed conditions of plants); however, the $\mathrm{TI}_{\mathrm{b}}$ value was 1 for the treatment of 50 $\mathrm{mg} \cdot \mathrm{kg}^{-1} \quad \mathrm{CuCl}_{2}$ (no difference relative to control treatment). According to $\mathrm{TI}_{\mathrm{b}}$ values, $S$. mucronata has suitable tolerance against $\mathrm{CdCl}_{2}, \mathrm{CuCl}_{2}$, and $\mathrm{Pb}$ acetate up to $40 \mathrm{mg}$, $150 \mathrm{mg}$, and $650 \mathrm{mg} \cdot \mathrm{kg}^{-1}$, respectively, whereas the $\mathrm{TI}_{\mathrm{b}}$ values for the aforementioned concentrations of these metals are more than 0.70 (or $70 \%$ ). Metal tolerance and uptake were found to be speciesdependent and willow clone-dependent (Dickinson et al., 1994). Additionally, plant biomass, metal tolerance, and metal accumulation patterns in roots and leaves varied greatly between 20 different clones of willow and poplar species (Dos Santos Utmazian et al., 2007).

In conclusion, $S$. mucronata tolerated $\mathrm{CdCl}_{2}, \mathrm{CuCl}_{2}$, and $\mathrm{Pb}$ acetate up to 80,200 and $850 \mathrm{mg} \cdot \mathrm{kg}^{-1}$, respectively, with $100 \%$ survival. Accumulations of $\mathrm{Cd}, \mathrm{Cu}$, and $\mathrm{Pb}$ in the roots were greater than those in the aerial parts; therefore, the risk of contamination of the wider environment from falling leaves can be considered minimal. Based on BCF, $\mathrm{TF} \%$, and $\mathrm{TI}_{\mathrm{b}}$ data, $S$. mucronata is suitable for use as a phytostabilizer for $\mathrm{Cd}$ and $\mathrm{Cu}$ and as a phytoextractor for $\mathrm{Pb}$-contaminated soil.

\section{Literature Cited}

Aebi, H. 1984. Catalase in vitro. Methods Enzymol. 105:121-126.

Ahmad, P., E.F.A. Allah, A. Hashem, M. Sarwat, and S. Gucel. 2016. Exogenous application of selenium mitigates cadmium toxicity in Brassica juncea L. (Czern \& Cross) by upregulating the antioxidative system and secondary metabolites. J. Plant Growth Regul. 35:936-950. 
Basa, B., G. Lattanzio, A. Solti, B. Tóth, J. Abadia, F. Fodor, and E. Sárvári. 2014. Changes induced by cadmium stress and iron deficiency in the composition and organization of thylakoid complexes in sugar beet (Beta vulgaris L.). Environ. Exp. Bot. 101:1-11.

Black, C.A. 1965. Methods of soil analysis part I no. 9. Amer. Soc. Agron. Madison, WI.

Bremner, J.M. and C.S. Mulvaney. 1982. Nitrogen total, p. 595-624. In: A.L. Page (ed.). Methods of soil analysis. Agron. No. 9 Part II; Chemical and microbiological properties, 2nd ed. Amer. Soc. Agron., Madison, WI.

Campbell, P.G.C. 2007. Cadmium-A priority pollutant. Environ. Chem. 3:387-388.

Chemists, A.A. and W. Horwitz. 1990. Official methods of analysis. Vol. I. 15th ed. AOAC, Arlington, VA.

Chen, L.M., C.C. Lin, and C.H. Kao. 2000. Copper toxicity in rice seedlings: Changes in antioxidative enzyme activities, $\mathrm{H}_{2} \mathrm{O}_{2}$ level, and cell wall peroxidase activity in roots. Bot. Bull. Acad. Sin. 41:99-103.

Cottenie, A., M. Verloo, M. Velghe, and R. Camerlynek. 1982. Chemical analysis of plant and soil, Laboratory of Analytical and Agrochemistry. State Univ. Ghent, Belgium.

Dickinson, N.M., T. Puchon, R.B. Hodiknson, and N.W. Lepp. 1994. Metal tolerance and accumulation in Willows. Willow vegetation filters for municipal wastewaters and sludges, A biological purification system. Proc. Conf. Sweden, Sect. Short Rot. Forest Uppsala, 121-127.

Dimitriou, I., B. Mola-Yudego, P. Aronsson, and J. Eriksson. 2012. Changes in organic carbon and trace elements in the soil of willow shortrotation coppice plantations. BioEnergy Res. 5:563-572.

Dos Santos Utmazian, M.N., G. Wieshammer, R. Vega, and W.W. Wenzel. 2007. Hydroponic screening for metal resistance and accumulation of cadmium and zinc in twenty clones of willows and poplars. Environ. Pollut. 148:155165.

Drzewiecka, K., M. Mleczek, M. Gasecka, Z. Magdziak, A. Budka, T. Chadzinikolau, and Z. Kaczmarek. 2017. Copper and nickel cotreatment alters metal uptake and stress parameters of Salix purpurea $\times$ viminalis. J. Plant Physiol. 216:125-134.

Emamverdian, A., Y. Ding, F. Mokhberdoran, and Y. Xie. 2018. Antioxidant response of bamboo (Indocalamus latifolius) as affected by heavy metal stress. J. Elem. 23:341-352.

Ercan, F.S., N. Ercan, and D.D. Yilmaz. 2018. Effect of heavy metal stress on antioxidant enzymes and DNA damage in Nasturtium officinale R.Br. (watercress). Toxin Rev. 110, doi: 10.1080/15569543.2018.1471091.

Evenhuis, B. and P.W.F. de Waard. 1980. Principles and practices in plant analysis. Soil and Plant Testing and Analysis. FAO Soils Bull. 38:152-163.

Fahmy, I.R. 1948. A comparative study of Salix species grown in Egypt. J. Amer. Pharm. Assoc. 37:276-283.

Fargasova, A. 2004. Toxicity comparison of some possible toxic metals $(\mathrm{Cd}, \mathrm{Cu}, \mathrm{Pb}, \mathrm{Se}, \mathrm{Zn})$ on young seedlings of Sinapis alba L. Plant Soil Environ. 50:33-38.

Fodor, F., L. Gáspár, F. Morales, Y. Gogorcena, J.J. Lucena, E. Cseh, K. Kröpfl, J. Abadia, and É. Sárvári. 2005. The effect of two different iron sources on iron and cadmium allocation in cadmium exposed poplar plants (Populus alba L.). Tree Physiol. 25:1173-1180.
Gasecka, M., M. Mleczek, K. Drzewiceka, Z. Magdziak, I. Rissmann, T. Chadzinikolau, and P. Golinski. 2012. Physiological and morphological changes in Salix viminalis L. as a result of plant exposure to copper. J. Environ. Sci. Health Part A Toxic/Hazardous Substances and Environmental Engineering 47:548-557.

Gee, G.W. and J.W. Balder. 1986. Particle-size analysis, p. 383-411. In: A.L. Page (ed.). Methods of soil analysis, part I. Soil. Soc. of Amer., Inc., Madison, WI.

Hammerschmidt, R., E.M. Nuckles, and J. Kuc. 1982. Association of enhanced peroxidase activity with induced systemic resistance of cucumber to Colletrotrichum lagenarium. Physiol. Plant Pathol. 20:73-82.

Harada, J., A. Kim, A.J. Meyer, R. Hell, S. Clemens, and Y.E. Choi. 2010. Expression profiling of tobacco leaf trichomes identifies genes for biotic and abiotic stresses. Plant Cell Physiol. 10:1627-1637.

Hegedus, R., T. Kosaros, D. Gal, F. Pekar, M. Bırone Oncisk, and G. Lakatos. 2009. Potential phytoremediation function of energy plants (Tamarix tetranda Pall. and Salix viminalis L.) in effluent treatment of an intensive fish farming system using geothermal water. Acta Universitatis Sapientiae Agr. Environ. 1:3137.

Herbert, D., P.J. Phipps, and R.E. Strange. 1971. Determination of total carbohydrates. Methods Microbiol. 5:290-344.

Jackson, M.L. 1973. Soil chemical analysis. Prentice Hall of India, Private Limited, New Delhi.

Jing, D., W.U. Fei-bo, and Z. Guo-ping. 2005. Effect of cadmium on growth and photosynthesis of tomato seedlings. J. Zhejiang Univ. Sci. B 6:974-980.

Jopony, M. and S.D. Young. 1994. The solidsolution equilibria of lead and cadmium in polluted soils. Eur. J. Soil Sci. 45:59-70.

Kabata-Pendias, A. and H. Pendias. 1999. Biogeochemia pierwiastko'w s'ladowych. Biogeochemistry of trace elements, 3rd ed. Wyd. Naukowe PWN, Warsaw (in Polish).

Kersten, G.J. 2015. Phytoremediation of metal contamination using Salix (willows). M.Sc. thesis; The Faculty of Natural Sciences and Mathematics, University of Denver, CO.

Kim, S., M. Jung, and Y. Lee. 2011. Effect of heavy metals on the antioxidant enzymes in the marine ciliate Euplotes crassus. Toxicol. Environ. Health Sci. 3:213-219.

King, L.D. 1988. Retention of metals by several soils of the southeastern United States. J. Environ. Qual. 17:239-246.

Krajcarova, L., K. Lucie, N. Karel, C.H. Barbora, and E. Josef. 2016. Elemental analysis of soils and Salix polaris in the town of Pyramiden and its surroundings (Svalbard). Environ. Sci. Pollut. Res. Intl. 23:10124-10137.

Kupper, H. 2017. Lead toxicity in plants. Met. Ions Life Sci. 17:491-500.

Liu, D., W. Jiang, C. Liu, C. Xin, and W. Hou. 2000. Uptake and accumulation of lead by roots, hypocotyls and shoots of Indian mustard [Brassica juncea (L.)]. Bioresour. Technol. 71(3):273-277.

Liu, J., Z. Xiong, T. Li, and H. Huang. 2004. Bioaccumulation and ecophysiological responses to copper stress in two populations of Rumex dentatus $\mathrm{L}$. from $\mathrm{Cu}$-contaminated and non-contaminated sites. Environ. Exp. Bot. 52:43-51.

Liu, D., T.Q. Li, X.F. Jin, X.E. Yang, E. Islam, and Q. Mahmood. 2008. Lead-induced changes in the growth and antioxidant metabolism of the lead accumulating and non-accumulating eco- types of Sedum alfredii. J. Integr. Plant Biol. 50:129-140.

Lux, A., M. Martinka, M. Vaculik, and P.J. White. 2011. Root responses to cadmium in the rhizosphere: A review. J. Expt. Bot. 62:21-37.

Maiti, S.K. and S. Jaiswal. 2008. Bioaccumulation and translocation of elements in the natural vegetation growing on fly ash lagoons: A field study from Santaldih thermal power plant, West Bengal, India. Environ. Monit. Assess. 136:355-370.

Malik, C.P. and M.B. Singh. 1980. Plant enzymology and histoenzymology. Kalyani India, Navin, Shanndara, Delhi.

Markwell, J., J.C. Osterman, and J.L. Mitchell. 1995. Calibration of the Minolta SPADA-502 leaf chlorophyll meter. Phytosyn. Res. 46:467472.

McGrath, S.P., J. Zhao, and E. Lombi. 2002. Phytoremediation of metals, metalloids, and radionuclides. Adv. Agron. 75:1-56.

Mleczek, M., M. Ga, and P.Á. Willow. 2013. Copper phytoextraction with willow (Salix viminalis $\mathrm{L}$.) under various $\mathrm{Ca} / \mathrm{Mg}$ ratios. Part 1. Copper accumulation and plant morphology changes. Acta Physiol. Plant. 35:3251-3259.

Mosseler, A. and J.E. Major. 2017. Phytoremediation efficacy of Salix discolor and S. eriocephela on adjacent acidic clay and shale overburden on a former mine site: Growth, soil, and foliage traits. Forests $8: 475$.

Mourato, M., R. Reis, and L.L. Martins. 2012. Characterization of plant antioxidative system in response to abiotic stresses: A focus on heavy metal toxicity, p. 23-44. In: G. Montanaro and B. Dichio (eds.). Advances in selected plant physiology aspects. In Tech, Vienna, Austria.

Murphy, J. and J.P. Riley. 1962. A modified single solution method for the determination of phosphate in natural waters. Anal. Chim. Acta 27:31-36.

Nelson, D.W. and L.E. Sommers. 1996. Total carbon, organic carbon, and organic matter, $p$. 961-1010. In: C.A. Black (ed.). Methods of soil analysis. Part 3. Chemical methods. Soil Science of America and American Society of Agronomy, Madison, WI.

Nicholls, A.M. and T.K. Mal. 2003. Effects of lead and copper exposure on growth of an invasive weed, Lythrum salicaria L. (Purple Loosestrife) 103:129-133.

Niu, Z., S. Sun, T. Sun, Y. Li, and H. Wang. 2007. Evaluation of phytoextracting cadmium and lead by sunflower, Ricinus, alfalfa and mustard in hydroponic culture. J. Environ. Sci. 19:961967.

Olsen, S.R. and L.E. Sommers. 1982. Phosphorus, p. 403-430. In: A.L. Page (ed.). Methods of soil analysis. Agron. No. 9, Part 2; Chemical and microbiological properties, 2nd ed. Amer. Soc. Agron. Madison, WI.

Page, A.L., R.H. Miller, and D.R. Keeny. 1982. Methods of soil analysis, Part ii. 2nd ed. Agronomy Monogr. ASA and SSSA, Madison, WI.

Pourrut, B., M. Shahid, C. Dumat, P. Winterton, and E. Pinelli. 2011. Lead uptake, toxicity, and detoxification in plants. Rev. Environ. Contam. Toxicol. 213:113-136.

Pulford, I. and D. Waston. 2003. Phytoremediation of heavy metals contaminated land by trees. Environ. Inter. 29:529-540.

Rakhshaee, R., M. Giahi, and A. Pourahmad. 2009. Studying effect of cell wall's carboxylcarboxylate ratio change of Lemna minor to remove heavy metals from aqueous solution. J. Hazard. Mater. 163:165-173. 
Robinson, B.H., T.M. Mills, D. Petit, L.E. Fung, S.R. Green, and B.E. Clothier. 2000. Natural and induced cadmium accumulation in poplar and willow: Implications for phytoremediation. Plant Soil 227:301-306.

Santos, C., M. Monteiro, and M.C. Dias. 2010. Cadmium toxicity in crops: A review. Nova Science Publisher Inc., New York, NY.

Sarwar, N., S.S. Malhi, M.H. Zia, A. Naeem, S. Bibi, and G. Farid. 2010. Role of mineral nutrition in minimizing cadmium accumulation by plants. J. Sci. Food Agr. 90:925-937.

Schmidt, U. 2003. Enhancing phytoextraction. J. Environ. Qual. 32:1939-1954.

Sharma, M.S.R. and N.S. Raju. 2013. Correlation of heavy metal contamination with soil properties of industrial areas of Mysore, Karnataka, India by cluster analysis. Intl. Res. J. Environ. Sci. 2:22-27.

Sharma, P., A.B. Jha, R.S. Dubey, and M. Pessarakli. 2012. Reactive oxygen species, oxidative damage, and antioxidative defense mechanism in plants under stressful conditions. J. Bot. 2012:26-34.

Sharma, R.K., S. Devi, and P.P. dan Dhyani. 2010. Comparative assessment of the toxic effects of copper and cypermethrin using seeds of Spinacia oleracea L. plants. Trop. Ecol. 51:375-387.

Smith, S.R. and K.E. Giller. 1992. Effective Rhizobium leguminosarum biovar Trifolii present in five soils contaminated with heavy metals from long-term applications of sewage sludge or metal mine spoil. Soil Biol. Biochem. 24:781-788.
Szalai, G., T. Janda, E. Páldi, and Z. Szigeti. 1996. Role of light in the development of postchilling symptoms in maize. J. Plant Physiol. 148:378-383.

Tang, C., J. Songa, X. Hua, X. Hu, Y. Zhaob, B. Lia, D. Oua, and L. Pengaa. 2017. Exogenous spermidine enhanced $\mathrm{Pb}$ tolerance in Salix matsudana by promoting $\mathrm{Pb}$ accumulation in roots and spermidine, nitric oxide, and antioxidant system levels in leaves. Ecolog. Engin. 107:41-48.

Tauqeer, H.M., S. Ali, M. Rizwan, Q. Ali, R. Saeed, U. Iftikhar, R. Ahmad, M. Farid, and G.H. Abbasi. 2016. Phytoremediation of heavy metals by Alternanthera bettzickiana: Growth and physiological response. Ecotoxicol. Environ. Saf. 126:138-146.

Tu, S., L.Q. Ma, A.O. Fayiga, and E.J. Zillioux. 2004. Phytoremediation of arsenic-contaminated groundwater by the arsenic hyperaccumulating fern Pteris vittata L. Intl. J. Phytoremediation 6:35-47.

Vervaeke, P., S. Luyssaert, J. Mertens, E. Meers, F.G. Tack, and N. Lust. 2003. Phytoremediation prospects of willow stands on contaminated sediments: A field trial. Environ. Pollut. 126:275-282.

Viehweger, K. 2014. How plants cope with heavy metals. Bot. Stud. 55:1-12.

Vysloužilová, M., M. Puschenreiter, G. Wieshammer, and W.W. Wenzel. 2006. Rhizosphere characteristics, heavy metal accumulation and growth performance of two willow (Salix $\times$ rubens) clones. Plant Soil Environ. 52:353361.

Wilkins, D.A. 1978. The measurement of tolerance to edaphic factors by means of root growth. New Phytol. 80:623-633.

Wuana, R.A. and F.E. Okieimen. 2011. Heavy metals in contaminated soils: A review of sources, chemistry, risks and best available strategies for remediation. ISRN Ecol. 2011:1-20.

Yruela, I. 2009. Copper in plants: Acquisition, transport and interactions. Funct. Plant Biol. 36:409-430.

Yuan, H.M., H.H. Xu, W.C. Liu, and Y.T. Lu. 2013. Copper regulates primary root elongation through PIN1-mediated auxin redistribution. Plant Cell Physiol. 54:766-778.

Zacchini, M., F. Pietrini, G. Scarascia Mugnozza, V. Iori, L. Pietrosanti, and A. Massacci. 2009. Metal tolerance, accumulation and translocation in poplar and willow clones treated with cadmium in hydroponics. Water Air Soil Pollut. 197:23-34.

Zalesny, R.S., J.A. Stanturf, E.S. Gardiner, J.H. Perdue, T.M. Young, D.R. Coyle, W.L. Headlee, G.S. Banuellos, and A. Hass. 2016. Ecosystem services of woody crop production systems. BioEnergy Res. 9:465-491.

Zou, J., G. Wang, J. Ji, J. Wang, H. Wu, Y. Ou, and B. Li. 2017. Transcriptional, physiological and cytological analysis validated the roles of some key genes linked Cd stress in Salix matsudana Koidz. Environ. Exp. Bot. 134:116-129. 